\title{
Teknik Survei Situs Terbuka
}

\section{Baskoro Daru Tjahjono}

Keywords: method, theory, practices, data gathering, survey

\section{How to Cite:}

Tjahjono, B. D. (2000). Teknik Survei Situs Terbuka. Berkala Arkeologi, 20(1), 1-7. https://doi.org/10.30883/jba.v20i1.801

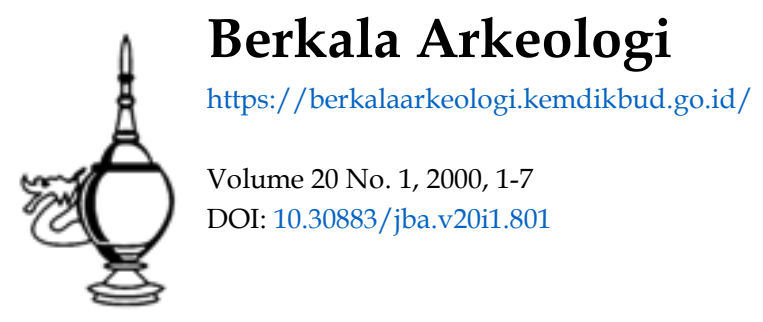

\section{c) (i) (5)}

This work is licensed under a Creative Commons Attribution-NonCommercial-ShareAlike 4.0 International License. 


\title{
TEKNIK SURVEI SITUS TERBUKA
}

\author{
Baskoro Daru Tjahjono \\ (Balai Arkeologi Yogyakarta)
}

\section{Pendahuluan}

Survei adalah salah satu teknik pengumpulan data dalam penelitian arkeologi di lapangan. Teknik pengumpulan data lain adalah ekskavasi. Jika dalam ekskavasi aktivitasnya dilakukan dengan membuka lapisan tanah, survei dilakukan tanpa membuka lapisan tanah. Dengan demikian resiko kerusakan data arkeologi yang disebabkan oleh kegiatan survei lebih kecil jika dibandingkan dengan ekskavasi.

Pada awalnya survei hanyalah kegiatan yang dilakukan untuk mengawali suatu penelitian arkeologi secara sistematis yaitu melalui ekskavasi. Pada tingkat ini survei masih dilakukan atas dasar intutif, dan belum dianggap sebagai teknik pengumpulan data yang sistematis. Teknik pengumpulan data arkeologi yang dianggap sistematis ban dilaksanakan pada saat ekskavasi. Namun bersamaan dengan beralihnya pusat perhatian dalam penelitian arkeologi dari tingkat situs ke tingkat wilayah, maka perhatian terhadap teknik survei yang sistematis semakin intensif. Pada saat itu survei dianggap telah setaraf dengan ekskavasi.

Survei bisa dilaksanakan pada situs-situs terbuka dan situs-situs tertutup. Situs-situs terbuka antara lain berupa situs-situs dengan tinggalan-tinggalan arkeologi di atas permukaan tanah, sedangkan situs tertutup misalnya situs-situs gua atau situs-situs dengan tinggalan arkeologis di dalam tanah. Pada kesempatan ini pembahasan difokuskan pada teknik survei pada situs-situs terbuka.

Pada tulisan ini diharapkan tidak sekedar menyajikan teknik-teknik survei pada situssitus terbuka yang mungkin telah banyak dibicarakan para ahli dan telah diterapkan pada penelitian-penelitian arkeologi di Indonesia. Namun diharapkan juga dapat mencari alternatif penerapan teknik-teknik survei yang tepat untuk sebuah penelitian arkeologi. Untuk itu diusulkan adanya tema-tema khusus dalam sebuah penelitian arkeologi, jadi tidak sekedar penelitian yang bersifat artefaktual. Penelitian tematis yang dikaitkan dengan kewilayahan ini telah dirintis oleh Balai Arkeologi Yogyakarta semasa pemerintahan Drs. Nurhadi MSc. Tema-tema tersebut untuk membatasi permasalahan yang akan diteliti. Sedangkan kewilayahan untuk membatasi objekobjek fisik yang akan dijadikan data untuk memecahkan masalah penelitian. Dengan penelitian yang bersifat tematis itu pula maka tidak setiap data fisik di wilayah tertentu akan dikumpulkan, melainkan hanya data yang sesuai dengan tema penelitian. 
Dengan demikian diperlukan strategi khusus untuk pengumpulan datanya, agar penelitian lapangan berjalan efektif dan efisien.

\section{Macam-macam Teknik Survei Situs Terbuka}

Semua data arkeologi sebenarnya merupakan sebagian dari seluruh data potensial. Tidak mungkin untuk mengumpulkan seluruh data atau mengekskavasi semua situs yang pernah ada, tidak mungkin menemukan semua artefak dari satu tipe dan seterusnya. Walaupun seorang arkeolog diberi dana dan waktu yang tidak terbatas dan setiap data dari semua situs dapat dikumpulkan dengan cara-cara paling maju, namun data yang dikumpulkannya masih akan bersifat sampel yang tidak lengkap. Padahal waktu dan dana untuk penelitian selalu terbatas, sehingga jumlah data yang sebenarnya dikumpulkan sangat jauh dari data potensial (Miksic, 1991).

Survei adalah salah satu teknik pengumpulan data yang dipandang lebih efektif dan efisien jika dibandingkan dengan ekskavasi. Pertimbangannya antara lain, data dapat diperoleh dalam waktu lebih singkat dan wilayah yang luas, dengan pengeluaran biaya lebih rendah dibanding ekskavasi, tidak merusak situs, dan banyak masalah arkeologi dapat dijawab atas dasar penyebaran artefak antar situs tanpa harus menggali (Miksic, 1991).

Pada awalnya survei arkeologi masih dilakukan atas dasar pendapat dan pengalaman pribadi (intutif) mengenai daerah-daerah dan situs-situs yang paling potensial. Cara ini disebut reconnaissance atau judgment sampling. Sejak sekitar tahun 1950 mulailah dikembangkan pengambilan contoh dengan teknik yang sistematis. Pengambilan contoh secara sistematis ini ditujukan untuk mengurangi sejauh mungkin kesalahan dalam pemilihan contoh. Secara garis besar ada dua teknik dalam pengambilan contoh ini, yaitu sistem petak ( $\mathrm{grid}$ ) dan sistem jalur (transect) (Miksic, 1991). Pengambilan contoh dengan sistem petak (grid) ini, wilayah yang menjadi sasaran survei harus dibagi menjadi sejumlah satuan lebih kecil dengan ukuran yang sama. Dengan sebuah peta, satuan-satuan pengambilan contoh akan membentuk suatu pola kotak-kotak yang disebut pola grid.

Pengambilan contoh dengan sistem petak ini dapat dibagi dalam 7 teknik, yaitu :

1. Percontoh acak mumi (simple random sample)

2. Percontoh acak terlapis (stratified random sample)

3. Percontoh acak terlapis berbobot (stratified random sample with unequal proportion)

4. Percontoh geometris sistematis (systematic geometric sample)

5. Percontoh interval sistematis (systematic interval sample)

6. Percontoh bertingkat atau tata jenjang (hierarchical sample) 


\section{Percontoh sistematis berlapis tidak sejajar (stratified systematic unligned sample)}

Percontoh acak mumi (simple random sample), teknik ini membagi suatu wilayah dalam sejumlah satuan lebih kecil yang memiliki ukuran sama. Memakai sebuah peta, satuan-satuan pengambilan contoh akan membentuk pola kotak atau grid, yang masing-masing kotak diberi nomor. Cara ini dimungkinkan untuk menentukan tingkat keragaman yang ada pada situs-situs di daerah tertentu dibanding dengan situs daerah lainnya pada wilayah yang sama tetapi berbeda kurun waktu. Cara pengambilan contoh ini juga dapat memberikan informasi mengenai perbedaan dan kesamaan antar situs, fungsi, kurun waktu, atau aspek keruangannya beserta dengan variasi-variasi yang terdapat di dalamnya.

Percontoh acak terlapis (stratified random sample), teknik ini membagi wilayah pengambilan contoh menjadi beberapa kotak besar, sedangkan satu kotak kecil akan diambil dari masing-masing kotak besar tersebut untuk disurvei. Cara ini menjamin tidak akan terdapat daerah-daerah yang tidak disurvei, dan dipastikan bahwa pengambilan contoh akan dilakukan pada seluruh areal.

Percontoh acak terlapis berbobot (stratified random sample with unequal proportion), teknik ini hampir sama dengan percontoh acak terlapis, tetapi dengan memanfaatkan pengalaman dari si peneliti. Sebagai contoh, berdasarkan pengalaman sudah diketahui bahwa daerah dataran luas lebih potensial sebagai situs permukiman daripada daerah rawa dan gunung, sehingga perhatian utama akan diberikan kepada dataran dan lereng gunung dengan mengesampingkan puncak gunung, karena memang kurang potensial untuk menghasilkan situs-situs yang dicari, selain itu teknik ini dilakukan jika sumberdaya manusia terbatas.

Percontoh geometris sistematis (systematic geometric sample), teknik ini membagi suatu wilayah survei dalam beberapa titik pengambilan contoh, yang mempunyai jarak yang sama antara satu titik dengan titik lainnya. Pada setiap titik dibuat areal pengambilan contoh dalam ukuran yang lebih kecil, dan seluruh benda di areal tersebut diambil. Cara ini akan memberikan gambaran tentang pola sebaran benda arkeologi dan tingkat kepadatan, baik secara kuantitas maupun kualitas.

Percontoh interval sistematis (systematic interval sample), teknik ini menerapkan pola dasar yang sama dengan percontoh geometris sistematis, tetapi dilakukan di antara interval satuan-satuan pengambilan percontoh. Hal ini disebabkan oleh adanya ketentuan tentang sebaran bangunan-bangunan, misalnya candi yang direncanakan secara geometris. Pendekatan ini akan lebih baik diterapkan, karena memperkecil lolosnya identifikasi populasi percontoh dalam penerapan teknik percontoh geometris sistematis. 
Percontoh bertingkat atau tata jenjang (hierarchical sample), teknik ini membagi wilayah dalam sejumlah kotak besar yang kemudian dibagi dalam kotak-kotak lebih kecil. Dalam kotak-kotak besar, bagian-bagian yang kecil diberi perhatian khusus ditentukan terlebih dahulu, kemudian dilakukan pengambilan percontoh di kotakkotak kecil dengan jumlah yang sama dalam kotak yang besar.

Percontoh sistematis berlapis tidak sejajar (stratified systematic unligned sample), teknik ini membagi areal pengambilan contoh menjadi beberapa satuan yang lebih kecil, yang masing-masing akan diambil percontohnya, dan dilakukan secara sistematis dengan penerapan pola pengambilan contoh pada semua petak yang dibuat. Disebut tidak sejajar karena petak-petak tidak disusun dalam sebuah pola sejajar.

Sistem pemetikan sampel yang lain adalah sistem jalur (transect). Dengan teknik jalur (transect) penentuan pola pemetikan sampel tidak perlu didasarkan atas batas wilayah yang ditentukan sebelum survei dimulai. Sedangkan dengan sistem petak ( $\mathrm{grid}$ ) satuan-satuan sampel baru dapat dipilih setelah batas wilayah diketahui. Sistem jalur mempunyai 3 alternatif utama, yaitu :

1. Percontoh jalur memancar (radial transect sample)

2. Percontoh jalur sistematis (systematic transect sample)

3. Percontoh jalur acak (random transect sample)

Di antara teknik-teknik pengambilan contoh yang sering dilakukan di Indonesia adalah teknik percontoh jalur sistematis (Systematic transect sample). Contoh penerapan teknik ini antara lain survei Situs Caruban, Lasem, Jawa Tengah yang dilakukan oleh Tim dari Pusat Penelitian Arkeologi Nasional (Nastiti dan Rangkuti, 1988) dan survei di situs Trowulan, Mojokerto, Jawa Timur dalam rangka program IFSA yang juga diselenggarakan oleh Pusat Penclitian Arkeologi Nasional (Faizaliskandar, 1995).

Teknik survei lain adalah radial transect (jalur memancar), yaitu tempat-tempat yang disurvei terdiri dari beberapa jalur yang memencar dari satu titik pusat. Dengan tcknik ini, semua anggota tim berangkat dari pangkalan yang sama, kemudian berjalan keluar dari situs untuk mencari situs-situs lain. Teknik ini sebenarnya juga diterapkan pada survei-survei yang dilakukan secara intuitif. Namun pada survei intuitif arah masingmasing jalur ditentukan oleh jalan-jalan, sungai-sungai, maupun faktor alam dan buatan manusia yang memiliki potensial untuk menimbulkan penyimpangan terhadap hasil survei (Miksic, 1991).

Meskipun banyak perkembangan baru telah terjadi di bidang survei, namun Hole, seorang arkeolog memberi komentar bahwa pendekatan baru belum berhasil menunjukkan kemajuan berarti. Menurut pengamatannya, kebanyakan ahli arkeologi berasumsi bahwa cara-cara pengambilan contoh yang sesuai pada suatu tempat dan 
situasi secara otomatis akan dapat diterapkan pada semua tempat. Menurut Hole, seharusnya pelaksanaan survei disesuaikan dengan keadaan setempat, dan umpan balik dari informasi yang sudah dikumpulkan selalu diamati agar perbaikan teknik dapat diterapkan langsung. Hal ini menunjukkan bahwa berbagai cara pemetikan sampel sudah tersedia, sehingga seorang arkeolog harus menentukan alternatif mana yang tepat dalam keadaan tertentu yang dihadapinya. Teknik survei yang tepat pada suatu kesempatan tidak selalu tepat pada kesempatan dan keadaan yang lain (Miksic, 1991).

\section{Teknik Survei Situs Terbuka dalam Penelitian Tematis Kewilayahan}

Dimensi ruang dan waktu sangat penting bagi penelitian arkeologi, karena kesinambungan arkeologi itu berjalan melalui proses waktu yang berdomisili di wilayah atau kawasan tertentu di muka bumi. Difusi arkeologis itu terjadi melalui periode waktu yang cukup lama dan melalui kondisi geografis yang bervariasi. Oleh karena itu, studi ruang dalam arkeologi meliputi berbagai aspek kehidupan manusia masa lalu, baik ditinjau dari segi sosial-budaya, sosial-ekonomi, maupun dari segi eko-teknologisnya (Bintarto, 1995). Oleh karena itu, suatu studi arkeologi yang bersifat kewilayahan merupakan satu strategi bagi pengembangan penelitian arkeologi di Indonesia, khususnya Balai Arkeologi Yogyakarta, baik pengembangan wawasan akademik maupun yang dikaitkan dengan pembangunan nasional (Nurhadi, 1996). Selain penekanan pada studi kawasan maka pengembangan penelitian arkeologi di Balai Arkeologi Yogyakarta mengacu pada penelitian yang bersifat tematis.

Penelitian tematis kewilayahan adalah penelitian yang didasarkan pada topik-topik atau tema-tema penelitian tertentu pada suatu kawasan yang telah ditentukan Beberapa penelitian tematis kewilayahan pada situs-situs terbuka yang telah dikembangkan Balai Arkeologi Yogyakarta antara lain: Bentuk-bentuk Pemanfaatan Sumberdaya Alam Kawasan Pegunungan Selatan Jawa dan Interaksi Sosial Ekononi Masyarakat Pegunungan Selatan Jawa dengan Masyarakat Dataran Rendah (Penelitian Arkeologi Prasejarah). Budaya Marginal masa Klasik di Jawa Tengah bagian Baratlaut dan Pola Pemukiman Desa-desa Masa Majapahit di Timur Jawa: Penelitian di Kabupaten Mojokerto dan Kabupaten Pasuruan Jawa Timur (Penelitian Arkeologi Klasik), Sosialisasi Islam di Kawasan Pegunungan Menoreh, Sarana Pertahanan Kolonial di Kabupaten Ngawi, Kabupaten Bangkalan, dan Kabupaten Situbondo, Provinsi Jawa Timur (Penelitian Arkeologi Islam)

Dalam penelitian bertema kewilayahan ini luas wilayah yang akan diteliti telah ditentukan terlebih dahulu, bisa ditentukan berdasarkan kondisi geografis atau lokasi administratif. Wilayah atau kawasan yang didasarkan pada kondisi geografis misalnya kawasan Pegunungan Selatan Jawa, kawasan Pegunungan Menoreh, sedangkan yang 
didasarkan pada lokasi administratif misalnya kawasan Jawa Tengah bagian Baratlaut, dan lokasi administratif wilayah kabupaten atau provinsi dan lain-lain. Karena batasan wilayah ini bisa sangat luas maka diperlukan strategi khusus dalam pengumpulan datanya. Karena adanya keterbatasan waktu, tenaga, dan biaya, maka untuk menjangkau seluruh wilayah tersebut tidak mungkin dapat mengumpulkan seluruh data yang ada. Oleh karena itu yang dapat dilakukan hanya mengumpulkan sampel-sampel. Sedangkan teknik-teknik survei yang telah disebutkan di muka pada umumnya hanya efektif dilakukan pada wilayah atau kawasan yang tidak terlalu luas.

Oleh karena itu, untuk wilayah yang sangat luas yang dapat mencakup beberapa wilayah kabupaten, teknik survei yang dapat digunakan adalah purposif sampling, yaitu pengambilan sampel sesuai dengan tujuan penelitian yang didasarkan pada pertimbangan-pertimbangan tertentu yaitu adanya keterbatasan waktu, tenaga, dan dana. Dengan penelitian yang bersifat tematis ini pelaksanaan survei tidak dimaksudkan sekedar mencari data baru saja sebagaimana pada kegiatan inventarisasi Benda Cagar Budaya (BCB) atau survei intutif, melainkan menggunakan data yang sudah diinventaris tersebut untuk memecahkan masalah-masalah dalam penelitian. Dengan demikian, kemungkinan menemukan data baru juga sangat berguna untuk memperkuat data penelitian. Jadi jenis-jenis data yang akan dikumpulkan sudah ditentukan terlebih dahulu berdasarkan sumber sekunder.

Untuk penelitian tematis kewilayahan ini, maka strategi yang digunakan agar penelitian berjalan efektif dan efisien antara lain: Pertama, menentukan jenis data yang akan dikumpulkan baik arkeologis maupun data lingkungan yang sesuai dengan tema penelitian, kedua, mencari data inventarisasi BCB di wilayah yang akan diteliti melalui kantor Suaka Peninggalan Sejarah dan Purbakala (SPSP) setempat atau Kandepdikbud setempat, ketiga, seleksi data yang sesuai dengan tema penelitian, keempat, pelaksanaan survei di lapangan berdasarkan seleksi data di atas. Sedangkan untuk survei lingkungan secara khusus dapat dilakukan pengamatan lingkungan di sekitar situs, secara umum yang menyangkut kondisi geografis wilayah yang diteliti dapat dilakukan melalui data pokok pembangunan wilayah setempat, yang dikeluarkan oleh Bappeda.

\section{Penutup}

Teknik survei dalam penelitian arkeologi telah mengalami perkembangan pesat di era pertengahan abad 20 sehingga telah dapat disejajarkan dengan teknik ekskavasi. Pada saat itu teknik survei sebagai salah satu teknik pengumpulan data telah dilakukan secara sistematis. Sehingga muncul bermacam teknik survei sistematis, yang secara umum dapat dibagi dalam dua sistem yaitu sistem petak ( $\mathrm{grid}$ ) dan sistem jalur (transect). Namun teknik survei yang tepat pada suatu kesempatan tidak selalu tepat 
pada kesempatan dan keadaan yang lain. Dengan demikian dari berbagai cara pemetikan sampel yang sudah tersedia, seorang arkeolog harus menentukan alternatif mana yang tepat dalam keadaan tertentu yang dihadapinya. Demikian pula dengan pelaksanaan survei pada penelitian tematis kewilayahan dengan wilayah yang sangat luas diperlukan strategi khusus dalam pengumpulan datanya.

\section{KEPUSTAKAAN}

Bintarto, H. (1995). Keterkaitan Manusia, Ruang Dan Kebudayaan. Berkala Arkeologi, 15(3), 1-4. https://doi.org/10.30883/jba.v15i3.663

Faizaliskandiar, M. (1995). Sebaran Tembikar Di Trowulan: Hasil Survei IFSA 1991-1993. Berkala Arkeologi, 15(3), 150-167. https://doi.org/10.30883/jba.v15i3.688

Miksic, John N, 1991, Pemetikan Sampel, dalam Buku Acuan Kuliah Indonesian Field School of Archaeology, Trowulan 1-21 Juni 1991, Pusat Penelitian Arkeologi Nasional dan The Ford Fondation, him. 41-104.

Mundardjito, nfn. (1995). Kajian Kawasan: Pendekatan Strategis Dalam Penelitian Arkeologi Di Indonesia Dewasa Ini. Berkala Arkeologi, 15(3), 24-28. https:// doi.org/10.30883/jba.v15i3.666

Nastiti, Titi Surti dan Nurhadi Rangkuti, 1988, Laporan Penelitian Ekskavasi Caruban. Lasem, Jawa Tengah, Berita Penelitian Arkeologi No. 38, Jakarta.

Nurhadi, Tahun 1996/1997, Butir-butir Acuan Arkeologi Wilayah - Satu Strategi Pengembangan Penelitian di Lingkungan Balai Arkeologi Yogyakarta Menghadapi PJP-II, Jurnal Penelitian Arkeologi No. 04, Balai Arkeologi Yogyakarta. 